\title{
Application of Music in Class Management_Crazy for Music
}

\author{
Liu Yanpeng \\ Hengshui High School, Hengshui, Hebei 053000, China
}

Keywords: Music; class management; application

\begin{abstract}
By searching the literature, the research on the application of music education in class management is very few. This paper shows the application of music education in class management through five specific cases, that is singing competition, singing hiking, song education, singer display and song adaptation.
\end{abstract}

Confucius placed "music" second among the six arts. He believes that the culture of human began in the study of poetry, self-reliant in the ceremony and completed in music. So, what role does music play in class management? Please take a look at my music education story_—Mad for Music.

\section{First act in Mad for Music_—_sing competition spreads light}

I always remember that scene, 50 bodies closely clustering together. That is our chorus team, and Defending the Yellow River is our song. Music is like a ray of sunshine in our hearts.

At the beginning of a class, the school planned to hold a singing competition. How to complete this task while students aren't familiar with each other? The class committee suggested to sing revolutionary songs, which can not only improve class morale and cohesion also won by novelty as other classes were more likely to choose popular songs. After discussion, we chose Defending the Yellow River, a song written by Guang Weiran and composed by Xian Xinghai, which warmly praised the Chinese people's firm and unyielding spirit of struggle, suitable for the new class to make concerted efforts. In order to achieve good performance, the class committee actively mobilized and made full preparations in the class. First, they watched the performance video to learn the rhythm, read the printed lyrics, and finally sang together to perform part singing, and the chorus effect was getting better and better. A conductor and four speechers were selected to assist the singing, and the conductor studied a special conductor video while the speechers prepared the speech draft and gave suggestions to each other. We used the breaks and self-study courses to practice intensively. All classmates seemed to become comrades, a cohesive class also slowly formed in the singing. On the day of the contest, they all stood on the stage in a neat line. Two speechers laid the foundation for the song and brought the audience into the context:"Looking back on yesterday's road, full of thorns and vicissitudes. When the Japs' sword pointed to north China, Yellow River, I heard you Shouting; When the Japanese aggressors trampled the Chinese civilization, the Yellow River, I heard you roar!” Next, the students sang "to protect the Yellow River" : "the wind is yelling, the horse is screaming, the Yellow River is growling, the Yellow River is growling." It 's full of that sound of the schoolmate, and all the people of the country cried out, "the Chinese people will never fall down and that China will not land." The performance of the students shocked the audience, and we won the first place in the singing contest. And this song has become our classic repertoire, whenever we encounter difficulties, we will think of this song, think of the class through the arduous process of growth, encouraging all teachers and students to forge ahead together.

And then we understood, where we were defending the Yellow River, and it was a class that was being defended, and it was not just a song, it was a song, it was a performance, it was a song, it was a class, it was a class, it was an indestructible team, and music was the light of our hearts. 


\section{The second act of my song crazy - singing hiking smile face}

Eighty miles of hiking - a large-scale activity of the school, currently to better hone the students' will, but the hiking distance students are also "daunting", but when the long road meets music, it is an art trip, let each students face the most beautiful smile.

For the trip, in order to achieve the goal of "journey of music", I have prepared a bluetooth speakers, back my satchel, place the bluetooth speakers in bags side bags, mobile phone to download a song in advance, add playlist, from children's songs to folk songs to rock and roll, these songs is my little surprise on hiking to the students. With music, our journey there seems to be the guide, the students of the energy is no longer on the long journey, but care about what I put down a song, and I also started the "classics", what want to listen to the song, I can just have directly using a mobile phone search, the long journey seems to be turned into a foot concert, watched the other class was tired, and my class spirit, more walk more spirit, when there is a vehicle passing by, we have to raise our voice to a song, have to thumb up for us fighting forces in the world. That day in the camp, played under light rain, suddenly the students seems to be not in the best shape, by this time I again remind of the music, the students we inclose, let an open-air concert is good, so we together, although the sky is still under a light rain, but we have opened a small concert, singing and clapping, express our joy to the sky and the earth ", he said wind and rain, this pain is nothing, wipe the tears, don't ask, "why we a person seems to be the brave sailor. On the way back, the students were already exhausted, we still used music to encourage themselves, in the music, it seems that the road is no longer far away, we discipline, we have high spirit, we accompanied along the way singing.

In that hiking, we remember deeply, we have already forgotten our fatigue and the long journey, we only remember the accompanying music, and the laughter of the road, music is our smiling face.

\section{I am crazy for the third act - song education communication bridge}

Love is the eternal topic of education, while music has become the best way for me to express my love. Every class meeting or festival, I will carefully select songs for the children, and these songs have become a bridge for me and my children to communicate with each other.

Most of these music came from the recommendation of my classmates. I selected some positive songs from them and played them at the right time. Students were very happy when they saw the recommended songs appeared in the class meeting. These songs not only show positive energy, but also play a very good education effect. In combination with the music video, students are either encouraged to inspire, or moved to tears. At this time, here and in this situation, music has become the best communication platform. On March 5th Learn from Lei feng Memorial Day, we listen to "Learn From Lei feng Good Example", understand Lei feng's advanced deeds; on Mother's Day together we "Listen To Mother's Words," lamenting "Where The Time Has Gone", experience the difficulty as a mother; on Father's Day, we watched the Prose Poem Written by My Father, sang "the Father" of "Chopsticks Brothers" together, and listened to the stories belonging to our fathers. On Wenchuan Anniversary of the Earthquake, we sing together "Life and Death is Inseparable," "no matter where you are I will find you", the melody sung by Jackie Chan is always engraved in heart; on the June 1st the Children's Day we sing together "the Calabash Baby", imagining oneself is "the Monkey King", release the child true nature freely; on August 1st the Army Day, "Unity Is Strength" also injected strength into the class. Our class also became a powerful collective in the singing, the moon is bright on August 15, "When did the bright moon first appear? Wine-cup in hand, I ask the blue sky", Wang fei's "May We all be Blessed with Longevity though Far part" makes us feel as if back to ancient times and feel the beauty Mid-Autumn festival; on September 10th the Teachers' Day, we all have a heart of gratitude for what our teachers has taught us; at the class meeting, we Shared each others' "Ideal", and talked freely about the story of dreams; "I and my proud obstinacy I sing loudly in the wind" "Obstinacy" we never give in, no matter what kind of difficulties the class encountered, we all bravely persevere down, with the song to remind ourselves again and again, persist to the end. The songs with relevant video effect will be better, the education 
the students received is no longer the teacher's oral lecture, but a subtle edification and infection.

\section{The fourth act of Crazy for the Song-_-The lyrics adapted, written in the heart}

We can sing other people's songs. In fact, we can also write our own stories, record our lives with music, depict dreams with lyrics, and make happiness tangible.

I remember that when I was about to leave the class, my classmates said goodbye, I was very sad, so I decided to use the lyrics to express my inner thoughts, and changed "The Same Table" to "Children of Class Three, Grade Five" to my children. On that day, all of us, all sitting in the big hall, first expressed their gratitude to the students, and then sang their own songs to everyone present, I know, this song contains me to the children. We are deeply grateful and blessed , the past events are back and the students and I also sang together. From then on, I adapted the lyrics and combined the songs with the education. For example, the online song "Our love is a serious waste of life", I changed it to "Our efforts are the best for life" "Our efforts It is for the outstanding life, brave and fearless, precious friendship is more united, we are as strong as iron, we pursue excellence, my future world will be transformed into a butterfly." Recently, there is a very hot song "Chengdu", I adapted and gave it to my children. "Walk with me on the beautiful campus, until the dreams in my heart are realized. Never pursue excellence. Be more excellent, work hard and calmly and wait until the dream is realized, enjoy the happiness. "The pursuit of excellence" is our school motto, written in the lyrics, engraved in the hearts of every classmate.

Each song carries a story, a feeling, a feeling, and tells the story of me and the children, and also the memory that everyone remembers together. These are the songs written in my heart.

The song contest spreads the light, the song hikes the smile face, the song education communication bridge, the singer shows the shiny specials, the lyrics are written in the atrium, we are such a special group, we are accompanied in the song, we grow up in the song, we are in the song to get the transformation and glory that belongs to us, my children and I are also relying on our own efforts to realize our dreams and enjoy the happy feeling together.

Confucius said in the "Book of Filial Piety": "It is easy to change the customs, not good at music." Music is the best means and means to purify the social atmosphere, shape people's character, reconcile class contradictions, and promote social development. Also let a class form a good class, what better than music?

\section{References}

[1] Hui Meng. Who took the songs of the children's hometown?_-Investigation and research on the current situation of local music courses in Chinese ordinary school music education. Music Exploration, 2016, 04:79-85.

[2] Honglin Wang.On the Quality Education Function of Campus Culture Construction in Middle School. Liaoning Education Research, No.1, 2001

[3] Ping Fan. Cultivation of Students' Psychological Quality in Vocal Music Teaching[J].Symphony(Journal of Xi'an Conservatory of Music), 2014,01:148-151.

[4] Yang Chen. Introduction to Research Methods of Mass Communication [M]. Beijing: China Renmin University Press, 2007. 